Vol. 39(2), pp. 144-164, Dec. 2020

ISSN 1821-536X (print)

ISSN 2619-8789 (electronic)
Tanzania Journal of Engineering and Technology Copyright () 2020 College of Engineering and

Technology, University of Dar es Salaam

Full Length Research Paper

\title{
Assessment of the Performance of Grinding Circuit for Buzwagi Gold Mine
}

\section{Alphonce Wikedzi}

Department of Chemical and Mining Engineering, University of Dar es Salaam, Tanzania Corresponding author: alpho20012001@ gmail.com

\begin{abstract}
It had been reported by the management of Buzwagi Gold Mine (BGM) that grinding circuit was designed to produce final product size of $125 \mathrm{~m}$, which had not been achieved for a long period of time under both, low to normal (i.e. 450-600 $\mathrm{t} / \mathrm{h})$ and high $($ i.e. $>650 \mathrm{t} / \mathrm{h})$ throughputs. Also, the performance behaviour of the circuit had not been reviewed after long time of operation. Hence, an evaluation study was conducted in order to recommend improvement in mine operations. The study was realized through three circuit survey campaigns and laboratory experimentations. From the surveys, size distributions and solids contents of the samples were determined for all selected circuit streams. Furthermore, grindability and work indices of the ores were determined through standard Bond tests. The standard Bond tests data revealed increased Bond work indices for currently treated ores vs. those during design, indicating change in ore hardness over the years. Consequently, a periodic review of the ore blends was recommended as harder material requires more energy, which increases operation costs. Such reviews could help in establishing better ore blending and optimum throughput for existing plant design. Furthermore, the SAG mill circuit indicated varying feed sizes (i.e. $x_{F}, 80$ $=102$ to $185 \mathrm{~mm}$ ) which could be rectified by closer monitoring and control of ratios for the Semi-Autogenous Grinding (SAG) mill feeders drawing the ore from the stockpile. The ball mill performance was poor as indicated by only 5-9 \% of $<125 \mu \mathrm{m}$ (target product) in the discharge. This had a direct impact on hydrocyclones, where significantly poor performance indicators were observed; coarser overflow $x_{P, 80}:>200 \mu \mathrm{m}$ as well as cut size, $x_{T}:>200 \mu \mathrm{m}$. Also, the Bond efficiency factors in the range of 48-61\% were obtained, indicating an inefficient operation that could only achieve targets by lowering the current throughput. Hence, an optimization study of the existing design through computer modelling and simulation is recommended. Through simulation of multi-effects, a deeper understanding of the efficiency problems for the BGM grinding will be facilitated and also may provide possible solutions.
\end{abstract}

Keywords: Comminution, Grinding circuit, SAG mill, Ball mill, Circuit survey, Bond work index, Bond efficiency factor, Gold ore blends.

INTRODUCTION

Comminution is one of the most important unit operations in mineral processing and chemical industry (Den1z, 2011; Fuerstenau et al., 2011). However, comminution processes are both energyintensive and expensive, with tremendous 
room for improvement. It is estimated that comminution accounts for up to $50 \%$ of the energy used in mining operations (Ballantyne et al., 2012; Boucaut, 2017; Curry et al., 2014; Jeswiet and Szekeres, 2016) and that only $1 \%$ to $2 \%$ of the supplied energy is effectively translated in the creation of new surface areas (Rosario, 2010; Tromans, 2008; Wills and Finch, 2016). The majority of this energy is lost as heat or mechanical energy due to the operating nature of mills, where energy transfer between grinding media and particles is unconstrained and completely random.

This expensive and inefficient comminution process also represents a significant fraction of the global electric power consumption. In the United States, it is estimated that $30 \%$ of the total energy costs consumed in mining industry goes for comminution processes (DOE indices for 2005) (NRC, 1981; Tromans, 2008). Thus, comminution energy makes around $0.39 \%$ of total national energy consumption. In Canada, in turn, the respective index comes to nearly $2 \%$, similarly in the Republic of South Africa. In Australia comminution consumes roughly $1.5 \%$ of total national energy (Tromans, 2008). It has to be noted that, USA, Canada, South Africa, and Australia are the leaders in the application of modern mining technology and in recent years the values of energy consumption indices have generally decreased as a result of the application of modern processing technologies and equipment, especially in ore preparation circuits. As a result of the above, it is estimated that industrial comminution processes can absorb from 3 to $5 \%$ of global electric energy consumption (Jeswiet and Szekeres, 2016; Saramak et al., 2010). These and many other statistics reveal the importance and impact of size reduction processes and the reason for the extensive amount of effort made on this subject over the last 50 years (Acar, 2013).
In recent years, there have been significant developments in comminution efficiency, both due to the expansion of machines with the capability to boost energy utilization, and also due to optimal design of grinding circuits and operating variables that enable more efficient application of existing machines (Vedat, 2011). However, as a consequence of depleting high-grade ores; the mining industry's future trends indicate that the need will continue to mine and treat low grade, finely disseminated ores at much higher tonnages and finer product size. The effective liberation of valuables from such ores remains one of the major challenges for the mining industry (Danha, 2013).

The combination of energy intensive and poor performance of comminution process implies that there is a great opportunity for significant energy and economic savings by the improvement of this process (Rosario, 2010). Even small improvements to the power utilization efficiency can have a significant influence on the economic performance of a plant. Hence, continued research and development that will contribute to continued efforts in improving these processes is necessary for the long-term viability of the mining industry.

Previous work by Wikedzi (2018) concentrated on grinding circuit performance, with the case of Buzwagi Gold Mine (BGM). The survey data collected at BGM plant between April and June 2015 indicated clearly that, by then, BGM grinding circuit was designed to produce final product size of $125 \mathrm{~m}$, which had not been achieved under both, low to normal (i.e. 450-600 t/h) and high (i.e. $>650 \mathrm{t} / \mathrm{h}$ ) throughputs (Figure 1). It was also reported that the performance behavior of the circuit had not been reviewed after long time of operation. Such a situation was anticipated to have not only lowered the flotation 
performance, but also limited the state-ofthe-art data on the overall performance of the process plant.

Therefore, any effort aimed at improving the performance of the operation became necessary. This could be achieved through several full-scale plant surveys in order to analyze the state-of-the-art performance of the circuit as well as investigate and improve ore breakage and grindability properties through feed ore characterization. Furthermore, based on analysis of the survey data and feed ore characterization tests, circuit optimization opportunities could be identified and implemented. As BGM operations are close to an end, the study will help other mining operations with similar problem.

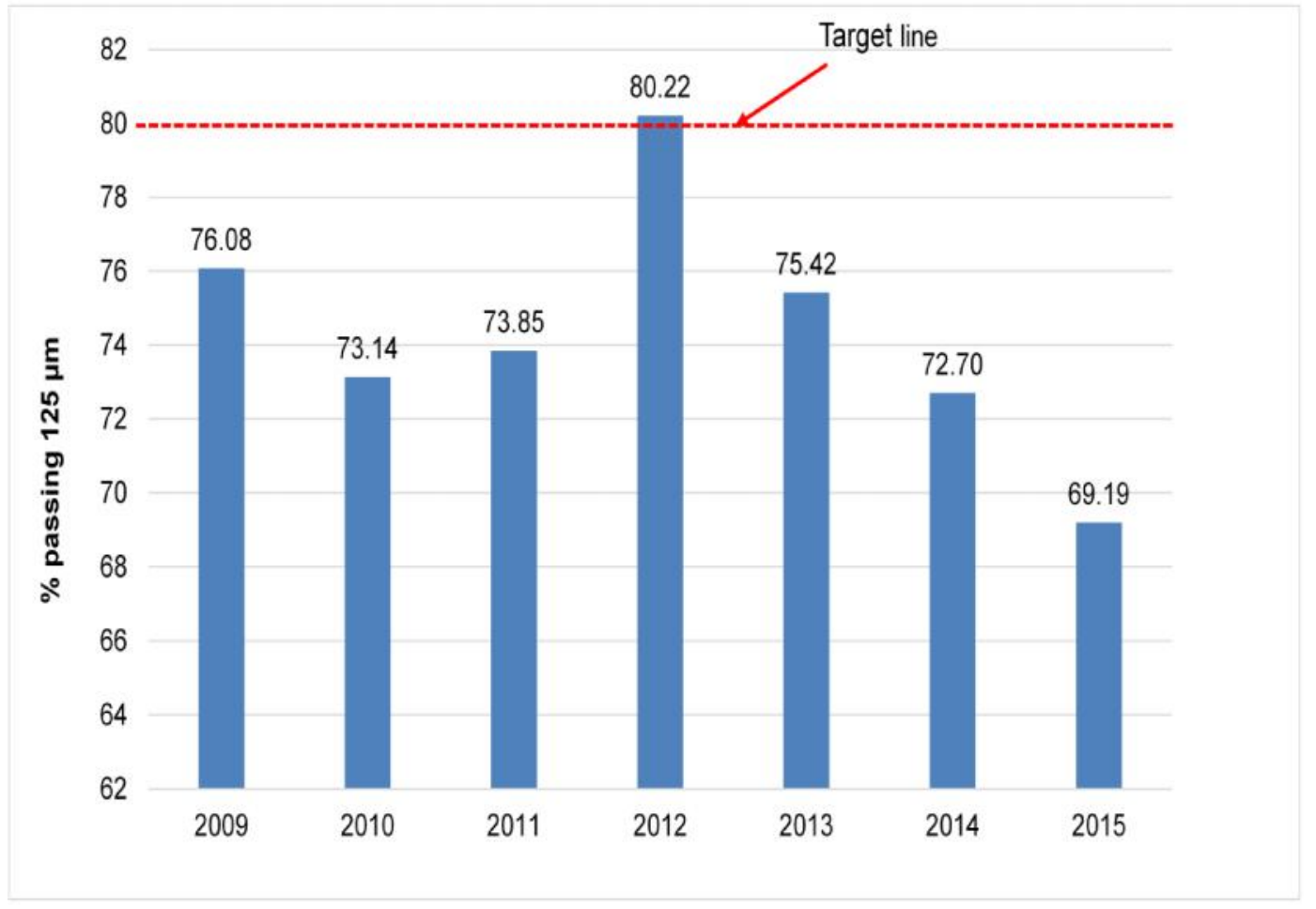

Figure 1: BGM grinding circuit efficiency trends from 2009 to 2015

\section{THEORY}

\section{Grinding Circuits Efficiency}

The most applicable technique in determining the efficiency of comminution circuits is the use of Bond efficiency factor $\left(B_{\mathrm{ef}}\right)$, which is the relative efficiency of the grinding circuit compared to the prescribed Bond standard energy for a 'conventional' grinding circuit (Rowland, 2008). The Bond efficiency factor is calculated as shown in equation (1).

$$
B_{e f}=\frac{W_{i}}{W_{i, o p}}
$$

Where $B_{\text {ef }}, W_{\mathrm{i}}$, and $W_{\mathrm{i}, \mathrm{op}}$ are Bond efficiency factor (\%), laboratory Bond index $(\mathrm{kWh} / \mathrm{t})$ and operating Bond work index $(\mathrm{kWh} / \mathrm{t})$, respectively. Efficiency factor values larger than $100 \%$ imply that the mill consumes less energy than the laboratory Bond tests estimate, and thus the throughput can be increased. On the contrary, efficiency values of less than $100 \%$ imply that the milling operation is inefficient and energy is wasted by the 
grinding operation (Alamouti et al., 2011; Rowland, 2008). The operating Bond index, $W_{\mathrm{i}, \mathrm{op}}$, can be determined from survey data by equation (2).

$$
W_{i, o p}=\frac{P}{\dot{m}\left(\frac{10}{\sqrt{x_{P, 80}}}-\frac{10}{\sqrt{x_{F}, 80}}\right)}
$$

Where $P$ is the circuit power in $\mathrm{kW}, \dot{m}$ is circuit throughput $(\mathrm{t} / \mathrm{h})$ and $x_{P, 80}$ and $x_{F, 80}$ are the circuit product and feed sizes, respectively.

The laboratory work index is obtained using the standard Bond test procedure and using Bond (Equation (8). This parameter is used for estimation of specific power requirements for industrial grinding mills (Rowland, 2006). The operating work index is the specific power consumption under real plant conditions based on known mill throughput, power draw and size distributions of feed and product. It is regularly used for monitoring energy efficiency of existing grinding circuits (Gupta and Yan, 2006; Napier-Munn et al., 1996; Rowland, 2006).

\section{Performance of Classification Processes}

It is a normal practice for most grinding circuits to be incorporated with classification devices (e.g. screens or hydrocyclones) which their main function is to remove the already ground material to the next unit operations. This step is important, otherwise, overgrinding can occur and cause unnecessary energy costs as well as metal losses. Ideally there is no technical classifier which can achieve $100 \%$ separation of the feed into a stream of fines only and another stream of coarse particles only at a defined cut size. Due to stochastic factors of particle collisions, turbulence and flow pattern within the separating medium some of the fine particles will report to the coarse stream and also some of the coarse particles will report to the stream of fine particles
(Khumalo, 2007; Schubert, 1985; Schubert and Mühle, 1991).

The efficiency of classification devices like screens and hydrocyclones is typically presented by the so called partition curve $T(\mathrm{x})$ (Figure 2), also known as performance curve (Gupta and Yan, 2006; Leißner et al., 2016; Schubert, 2003; Wills et al., 2006). The partition curve relates the weight fraction of each individual particle size which reports to the apex (also called underflow or coarse product stream), to the weight fraction of the same particle size in the feed. From the curve, the cut size $x_{\mathrm{T}}$ is defined as the size for which $50 \%$ of the particles in the feed report to the coarse product stream. Particles of this size have an equal chance of going either to the overflow or underflow stream.

It is worth to note that $T(\mathrm{x})$ does not pass through the origin due to the fact that, a fraction of particles bypasses the classifier and are not classified (Gupta and Yan, 2006), which is especially relevant for all (hydro-) dynamic classifiers. Thus, the cut size calculated from $T(\mathrm{x})$ has to be corrected in order to account for the bypass effect.

The usual symbol for the corrected cut size is $x^{\prime}$. The following equations are involved in the assessment of a given classifier:

$$
T(x)=\left(1-R_{m, f}\right) \frac{m_{C}(x)}{m_{F}(x)}
$$

Where: $R_{\mathrm{m}, \mathrm{f}}=$ Fraction of particles recovered in the fine product stream; $m_{\mathrm{C}}(\mathrm{x})$ $=$ weight fraction of particle size $\mathrm{x}$ in the coarser product stream; $m_{\mathrm{F}}(\mathrm{x})=$ weight fraction of particle size $\mathrm{x}$ in the feed stream

$$
\begin{gathered}
T^{\prime}(x)=\frac{T(x)-T_{o}}{1-T_{o}} . \\
x_{T}^{\prime}=T\left(x_{T}^{\prime}\right)=0.5
\end{gathered}
$$

where $T_{\mathrm{o}}=$ the splitting factor. 


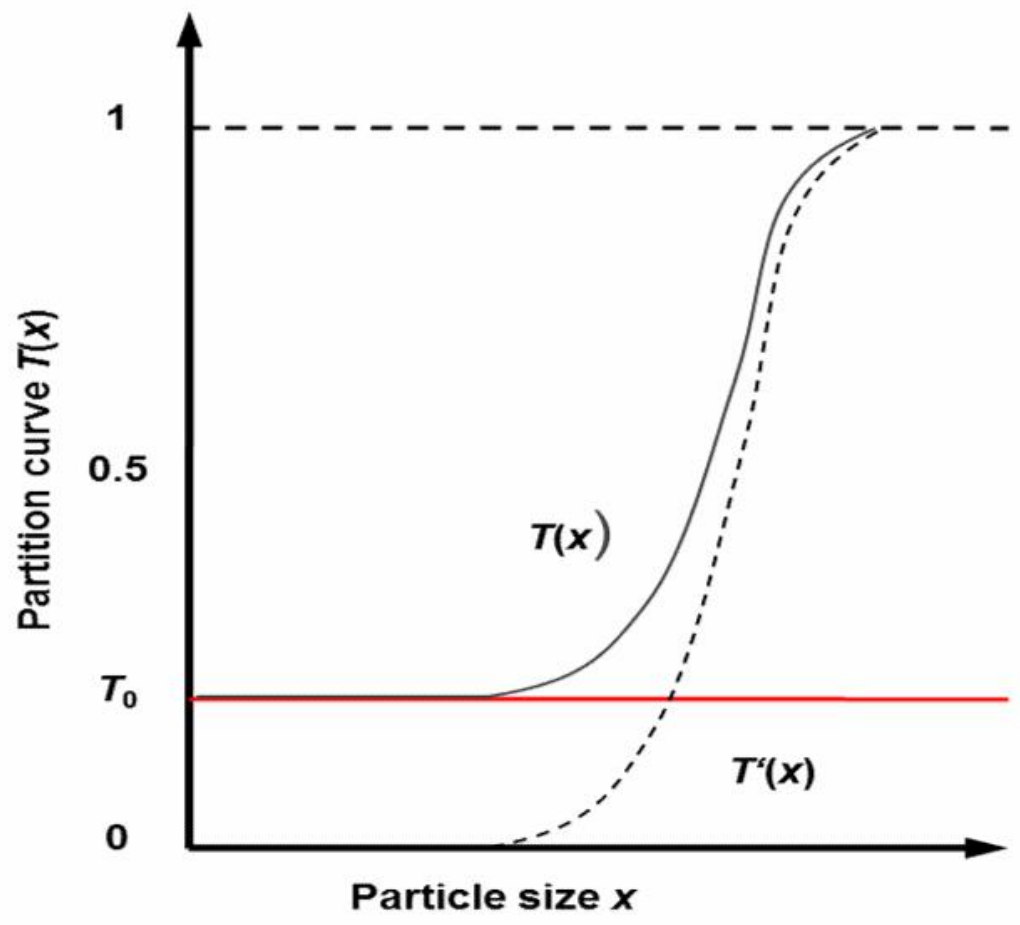

Figure 2: Typical partition curve for hydrocyclones

The sharpness of the cut is represented by the slope of the central section of the partition curve; the closer to vertical is the slope, the higher is the efficiency. The imperfection $(I)$ as well as efficiency of separation $(\kappa)$ are given by equations (6) and (7), respectively:

$$
\begin{aligned}
& I=\frac{x_{75}-x_{25}}{2 x_{50}} \\
& \kappa=\frac{x_{25}}{x_{75}} \ldots \ldots .
\end{aligned}
$$

$x_{25}$ and $x_{75}$ are sizes at which $25 \%$ and $75 \%$ of the feed particles report to the coarse stream.

\section{MATERIAL AND METHODS}

\section{BGM grinding Circuit Survey}

Comminution circuit survey is an essential tool for gaining an understanding of grinding operations over a particular time period. It involves collection of representative samples and operating data from the circuit over a particular operating period. However, a good survey has to be conducted based on the standard survey procedures and protocol as proposed by Napier-Munn and co-workers (Mular et al., 2002; Napier-Munn et al., 1996), which were also implemented in the current study.

For the purpose of this study, three full scale sampling survey campaigns, each lasting for a maximum period of 2 hours were implemented on the BGM grinding circuit. Prior to sampling, circuit operating conditions were monitored to ensure that the plant is under steady state conditions. This was verified by examining the real time circuit trends for the key circuit parameters from the control system for at least 2 hours.

The sampling and steady state monitoring points used for BGM grinding circuit are shown in Figure 3 and the respective samples collected are listed as follows:
1) SAG mill feed
2) SAG discharge screen undersize
3) Pebble crusher feed 
4) Pebble crusher product

5) Cyclone feed

6) Cyclone underflow
7) Cyclone overflow

8) Ball mill discharge

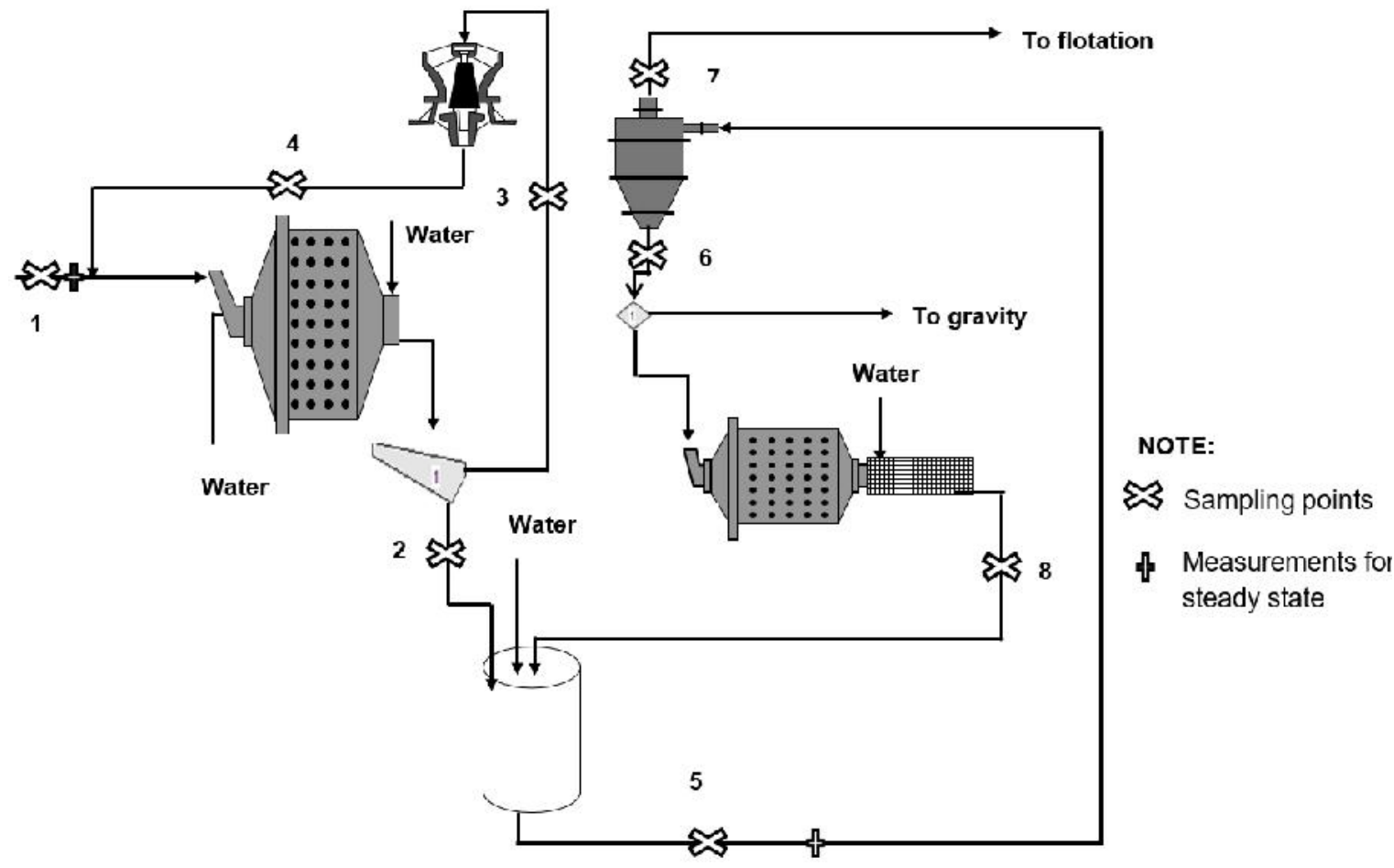

Figure 3: BGM grinding circuit flow sheet with sampling points.

Based on the design of the circuit, it was not possible to sample the SAG mill discharge. The flow rate for this stream was later determined from the mass balance of the other streams sampled. Also, it has to be realized that samples 1, 3 and 4 are mainly solids, while the rest are slurry. These two categories of samples were obtained as follows.

\section{SAG Mill Feed sampling}

The Semi-Autogenous Grinding (SAG) mill feed sample was obtained by stopping the circuit feed conveyor and then stripping the ore (belt cut sampling). The stripped conveyor length was 3-4 m. The quantities of the SAG feed samples collected were approx. 377.5, 341.2 and
$315 \mathrm{~kg}$, for sampling survey campaign 1, 2 and 3 , respectively.

\section{Pebble Crusher Feed and Product sampling}

In each survey, the pebble crusher feed sample was grabbed from the pebble crusher feed diverter chute after every 20 minutes interval by the aid of a shovel. Pebble crusher product samples were obtained from the pebble crusher product discharge chute using the same time interval, procedure, and device as for the feed. The quantities of samples collected for the pebble crusher streams for each survey are presented in Table 1.

Table 1: Total mass of samples collected for pebble crusher streams.

\begin{tabular}{|l|c|c|c|}
\hline \multirow{2}{*}{ Stream Name } & \multicolumn{3}{|c|}{ Surveys } \\
\cline { 2 - 4 } & S-1 & S-2 & S-3 \\
\hline Pebble crusher feed in kg & 27.74 & 33.45 & 40.42 \\
\hline Pebble crusher product in kg & 16.70 & 26.00 & 24.00 \\
\hline
\end{tabular}




\section{Sampling Slurry Streams}

Slurry sampling was done for the undersize material of the SAG discharge screen, the cyclone feed, overflow, and underflow as well as the ball mill discharge. During the whole campaign, each slurry stream was sampled every 15 minutes for a period of two hours. A total of 8 subsamples were collected to make the composite weight (i.e. Table 2) for the final sample. This was done in order to reduce possible sampling error due to operation or process fluctuations (i.e. plant dynamics). However, the other possible source of errors could be due to sample cutter design, sub-sampling (e.g. splitting) of primary sample, analytical errors (e.g. weighing, inadequate sieving time, etc.) as well as propagation errors due to calculation of quantities (e.g. solids concentration).

Table 2: Slurry streams composite sample weights collected.

\begin{tabular}{|l|c|c|c|}
\hline \multirow{2}{*}{ Stream/sample name } & \multicolumn{3}{|c|}{ Survey } \\
\cline { 2 - 4 } & $\mathrm{S}-1$ & $\mathrm{~S}-2$ & $\mathrm{~S}-3$ \\
\hline SAG discharge screen undersize in kg & 18.12 & 20.04 & 20.30 \\
\hline Ball mill product in kg & 7.15 & 20.30 & 20.80 \\
\hline Cyclone feed in kg & 14.22 & 17.66 & 20.83 \\
\hline Cyclone underflow in kg & 15.60 & 10.40 & 12.50 \\
\hline Cyclone overflow in kg & 6.60 & 7.80 & 9.90 \\
\hline
\end{tabular}

Napier-Munn and co-workers (NapierMunn et al., 1996) recommends the range of sample mass required for a representativeness of the survey campaign. All samples collected in this case were within this recommendation. In all of the proceeding sections, the notation S-1, S-2 and S-3 will be used to refer to survey 1 , survey 2 and survey 3 samples, respectively.

\section{Other Data Collected}

To successfully assess any grinding circuit, apart from material sampling exercise, also design and existing operating parameters of the circuit are required. Design parameters were obtained from the design documents and include equipment specification, equipment type and operating conditions. Current operating parameters were recorded from the control system and comprise of plant feed rate, grinding mills power draw, weight, water addition rate, speed as well as cyclone pressure. The mill ball load was determined by measuring the free height between balls load and the mill shell (Gupta and Yan, 2006; Napier-Munn et al., 1996) during plant breakdown, which occurred a day before survey. The details of the design parameters collected during the three full survey campaigns for the BGM grinding circuit are presented in Table 3.

\section{Processing of Samples}

All samples collected around the grinding circuit were dried and sieved in order to determine the solids content and particle size distributions. Slurry samples and pebble crusher samples were treated onsite, while the SAG mill feed samples were transported and processed at the Institute of Mechanical Process Engineering and Mineral Processing, TU Bergakademie Freiberg in Germany. Apart from particle size analysis, SAG mill feed samples were also used for standard Bond tests in order to determine ore grindability and work indices. 
Table 3: Summary of design criteria for BGM grinding circuit

\begin{tabular}{|l|c|c|c|c|}
\hline \multicolumn{1}{|c|}{ Design parameter } & SAG Mill & $\begin{array}{c}\text { Pebble } \\
\text { Crusher }\end{array}$ & Ball Mill & $\begin{array}{c}\text { Hydro- } \\
\text { cyclone }\end{array}$ \\
\hline Feed rate in $\mathrm{t} / \mathrm{h}$ & $460-543$ & 190 & & 1462 \\
\hline Feed $x_{\mathrm{F}, 80} \mathrm{in} \mathrm{mm}$ & 120 & & & \\
\hline Power in $\mathrm{kW}$ & 6000 & 315 & 6000 & \\
\hline Ball charge in \% volume & $15-20$ & & $30-35$ & \\
\hline Total charge in \% volume & $30-35$ & & & \\
\hline Critical speed in \% & 75 & & 75 & \\
\hline Ball size in mm & $65 / 90 / 120 / 150$ & & $80 / 65 / 50$ & \\
\hline CSS in mm & & $10-14$ & & \\
\hline Final product $x_{\mathrm{P}, 80}$ in $\mu \mathrm{m}$ & & & 125 & \\
\hline Bond Ball Mill Work Index in $\mathrm{kWh} / \mathrm{t}$ & & & $11.6-14.8$ & \\
\hline Bond Rod Mill Work Index in $\mathrm{kWh} / \mathrm{t}$ & & & $15.3-16.5$ & \\
\hline Pressure in $\mathrm{kPa}$ & & & & $80-110$ \\
\hline Circulating load in \% & & & & $250-350$ \\
\hline Overflow product $x_{\mathrm{P}, 80}$ in $\mu \mathrm{m}$ & & & & $100-125$ \\
\hline
\end{tabular}

\section{Particle Size Analysis}

The dried slurry samples used for percent solids determination were also used for particle size analysis. The sieving process and equipment/devices involved for all samples is well summarized in Table 4.

\section{The Standard Bond Test}

The three SAG mill feed samples (S-1, S2, and S-3) obtained from the belt cut of the feed conveyor were used for determination of their respective work indices. To obtain materials which are suitable for the standard Bond test, representative sub-samples were prepared from the bulk samples by stage laboratory crushing (jaw and cone crushers) to produce < $5 \mathrm{~mm}$ material, followed by splitting (riffle splitter). The standard Bond feed material $(<3.15 \mathrm{~mm})$ were obtained after further crushing with a laboratory jaw crusher. This general sample preparation procedure is shown in Figure 4.
Bond developed standard laboratory tests for the determination of crushability and grindability indices (Bond, 1952) and later modified it (Bond, 1961). The indices are the measure of material's resistance to breakage and are applicable in his empirical energy-size-reduction model to estimate the energy requirement in comminution (Masuda et al., 2007).

The standard Bond's test is a batch type dry test where the mill is operated in a locked cycle. The charge is ground for a number of mill revolutions, sieved on the desired screen to remove undersized material and then replacing the undersized material with new feed. The procedure is repeated until a constant mass ratio of 2.5 for oversize and undersize is achieved for three consecutive cycles (i.e. equilibrium condition). Mosher and co-worker (Mosher and Tague, 2001) found that the minimum number of cycles for the Bond test is seven, no matter how fast the steady state conditions are achieved. 
Table 4: Particle size analysis procedure for the survey samples.

\begin{tabular}{|c|c|c|}
\hline Sample & Procedure & Device/Equipment used \\
\hline SAG mill feed & $\begin{array}{l}\text { - Whole bulk sample used } \\
\text { - }>45 \mathrm{~mm} \text { : Manual sieving } \\
\text { - } \quad<45 \quad \mathrm{~mm}: \text { analytical } \\
\text { sieving machine }\end{array}$ & $\begin{array}{l}\text { - } 450 \mathrm{~mm} \text { sieves } \\
\text { - Sieve series in } \mathrm{mm}: 200,150,125,90,63 \text {, } \\
45,31.5,25,20,16,12.5,10\end{array}$ \\
\hline Pebble crusher feed & \multirow[t]{2}{*}{$\begin{array}{l}\text { whole weight of dried } \\
\text { sample was used }\end{array}$} & $\begin{array}{ll} & 450 \mathrm{~mm} \text { sieves } \\
\text { - } & \text { Sieve series in } \mathrm{mm}: 50,37.5,26.5,19,13.2,9.5\end{array}$ \\
\hline $\begin{array}{l}\text { Pebble } \quad \text { crusher } \\
\text { product }\end{array}$ & & $\begin{array}{ll}\text { - } & 450 \mathrm{~mm} \text { sieves } \\
\text { - } & \text { Sieve series in } \mathrm{mm}: 26.5,19,13.2,9.5,6.7 \\
& 4.75,3.35,2.36\end{array}$ \\
\hline Hydrocyclone feed & \multirow[t]{4}{*}{$\begin{array}{l}\text { Splitting dried samples to } \\
\text { obtain representative } \\
\text { subsample }\end{array}$} & $\begin{array}{ll}\text { - } & \text { Riffle splitter } \\
\text { - } & 200 \mathrm{~mm} \text { sieves } \\
\text { - } & \text { Sieve series in } \mathrm{mm:}: 4.75,3.35,2.36,1.7,1.18,\end{array}$ \\
\hline $\begin{array}{l}\text { Hydrocyclone } \\
\text { underflow }\end{array}$ & & \\
\hline Ball mill discharge & & \\
\hline $\begin{array}{l}\text { Hydrocyclone } \\
\text { overflow }\end{array}$ & & $\begin{array}{ll}- & \text { Riffle splitter } \\
\text { - } & 200 \mathrm{~mm} \text { sieves } \\
\text { - } & \text { Sieve series in } \mathrm{mm}: 0.425,0.3,0.212,0.15 \\
& 0.106,0.075,0.063\end{array}$ \\
\hline
\end{tabular}

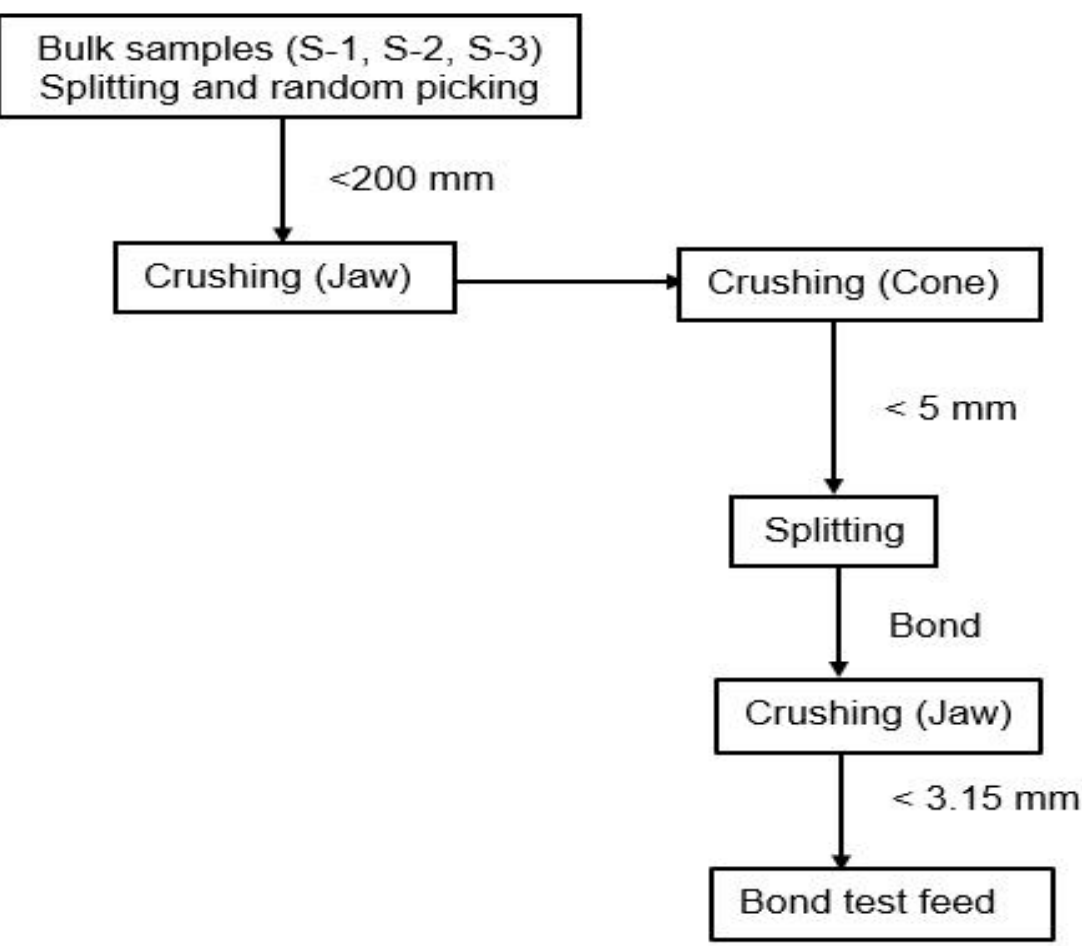

Figure 4: Overall preliminary sample preparation steps for the major tests

In this study, the standard Bond test protocols were adopted and the complete description of the test may be found elsewhere (Bond and Maxson, 1943;
Magdalinović, 1989; Man, 2002). The closing screen used for the investigation is $90 \mu \mathrm{m}$. The test gives the standard work 
index $\left(W_{\mathrm{i}}\right)$, which is calculated from Equation (8).

$$
W_{i}=\frac{44.5}{P_{1}^{0.23} \cdot G_{\mathrm{bp}}^{0.82} \cdot\left(\frac{10}{\sqrt{x_{\mathrm{P}, 80}}}-\frac{10}{\sqrt{x_{\mathrm{F}, 80}}}\right)}
$$

Where $x_{\mathrm{F}, 80}$ and $x_{\mathrm{P}, 80}$ are $80 \%$-passing size $(\mu \mathrm{m})$ of feed and product, respectively, $P_{1}$ is the test sieve size used $(\mu \mathrm{m})$, and $G_{\mathrm{bp}}$ is the net grams of sieve undersize material produced per mill revolution. Since Bond had used short tons to determine the work index equation (8), has to be multiplied by a factor of 1.1 in order to convert to metric tonnes. The work index of the material for the present work was calculated as an average of three tests conducted for each bulk sample. In this case, a 30.5 by $30.5 \mathrm{~cm}$, standard Bond mill was used for the dry tests. The mill design and operating variables for the mill are presented in Table 5. Moreover, the analysis of particle size distributions as well as work indices data were conducted by using excel.

Table 5: The standard Bond mill operating parameters used for the tests.

\begin{tabular}{|c|c|c|c|}
\hline \multirow{3}{*}{ Mill } & Inner diameter & $\mathrm{mm}$ & 305 \\
\hline & Length & $\mathrm{mm}$ & 305 \\
\hline & Volume & $\mathrm{cm}^{3}$ & 22273 \\
\hline \multirow[t]{2}{*}{ Mill speed } & Critical speed & $\mathrm{rpm}$ & 79.94 \\
\hline & Operational speed & $\mathrm{rpm}$ & $70.00(\psi=85 \%)$ \\
\hline \multirow{7}{*}{ Balls } & Material & & alloy steel balls \\
\hline & Diameter & $\mathrm{mm}$ & $19,25,38$ \\
\hline & Specific gravity & $\mathrm{g} / \mathrm{cm}^{3}$ & 7.81 \\
\hline & Number of balls & & 43 balls $\varnothing 38 \mathrm{~mm}$ \\
\hline & & & 109 balls $\varnothing 25 \mathrm{~mm}$ \\
\hline & & & 143 balls $\varnothing 19 \mathrm{~mm}$ \\
\hline & Total mass & $\mathrm{kg}$ & $20.55 \mathrm{~kg}$ \\
\hline \multirow[t]{3}{*}{ Material } & Gold ore & & \\
\hline & Specific gravity & $\mathrm{g} / \mathrm{cm}^{3}$ & 2.8 \\
\hline & Total material filling & $\mathrm{ml}$ & 700.00 \\
\hline
\end{tabular}

\section{RESULTS AND DISCUSSION}

\section{Grindability Studies}

The work index for the Buzwagi ore deposit estimated during the plant design was in the range of 14.5 to $16.5 \mathrm{kWh} / \mathrm{t}$. The currently treated ore blend's work indices (Table 6) ranged from 17.20 to $18.67 \mathrm{kWh} / \mathrm{t}$. These higher work indices indicate a change in hardness of the ore during the last 7 years.

Overall, higher work indices have a negative impact on the energy costs of milling. Also, as the mining progresses, new parts of the deposit may be discovered, which may have different characteristics from the original plant design. This situation requires a periodic re-assessment of the grindability and work indices of the different ore types encountered which was not done by BGM since plant commissioning. The indicated change in ore hardness is in agreement with studies by Abbey and co-workers (Abbey et al., 2015) who investigated the impact of mining depth on the ore work index and found that the competence of the ore and work indices increase with increasing mining depth.

Table 6: Ore work indices during design vs. the current operation (survey results) 


\begin{tabular}{|l|l|l|}
\hline Survey & $\begin{array}{l}\text { Measured } \\
(\mathrm{kWh} / \mathrm{t})\end{array}$ & $\begin{array}{l}\text { Design } \\
(\mathrm{kWh} / \mathrm{t})\end{array}$ \\
\cline { 1 - 2 } $\mathrm{S}-1$ & $17.20 \pm 0.15$ & \multirow{2}{*}{$14.50-16.5$} \\
\cline { 1 - 2 } $\mathrm{S}-2$ & $18.67 \pm 0.05$ & \\
\cline { 1 - 2 } $\mathrm{S}-3$ & $18.47 \pm 0.2$ & \\
\hline
\end{tabular}

\section{Grinding Circuit Mass Balance}

Table 7 shows the mass balance for key streams in the circuit. In all surveys, the throughput was higher up to $22 \%$ than the design capacity. Additionally, the designed circulating load of $250-350 \%$ is slightly lower than the average value found during the three surveys (375\%). This implies that the circuit was overloaded. Moreover, the SAG mill dilution ratio was higher for survey 1 (0.54) compared to survey 2 $(0.45)$ and survey $3(0.37)$. It is reported that the pulp density should be as high as possible so that the grinding media is coated with a layer of ore. If the pulp is too dilute, a metal to metal contact increases giving increased steel consumption and reduced grinding efficiency (Schlanz, 1987).

The fraction $<125 \mu \mathrm{m}$ (target size) in the ball mill product is considered as an indicator for the efficiency of the grinding stage. The results show that this fraction was only between 5 to $9 \%$. This poor performance might be due to the high circulating load of the ball mill circuit, which reduces the residence time of the material in the mill and hence leads to a coarser product.

\section{SAG Mill Circuit}

According to Figure 3, the SemiAutogeneous Grinding (SAG) mill at BGM is in closed circuit with a pebble crusher. The performance of the pebble crusher is indicated by the particle size distribution of feed and product streams (see Figure 5). The differences in product fineness for the three surveys has a direct relationship with pebble crusher throughput and ore hardness (i.e. the higher the throughput, the coarse the product and vice versa). Therefore, survey 1 (i.e. $61 \mathrm{t} / \mathrm{h}$ ) with the lowest throughput gave the finest product $\left(x_{\mathrm{P}, 80}=20 \mathrm{~mm}\right)$ than the other two surveys with $70 \mathrm{t} / \mathrm{h}$ $\left(x_{\mathrm{P}, 80}=23 \mathrm{~mm}\right)$ and $68 \mathrm{t} / \mathrm{h}\left(x_{\mathrm{P}, 80}=34 \mathrm{~mm}\right)$, respectively. Furthermore, the feed for surveys 2 and 3 were harder ore types than for survey 1 (see Table 6). When the feed becomes harder, the rate of breakage in the SAG mill decreases, leading to higher proportion of critical size product (pebbles), resulting to increased recycle load as reflected in the result (Pourghahramani, 2012).

Also, as it was expected, the product size $\left(x_{\mathrm{P}, 80}\right)$ correlates with the operating gap of the crusher (Table 8). However, it has to be noted that the crusher feed rate for all three surveys was significantly lower than the design capacity of $190 \mathrm{t} / \mathrm{h}$, implying that this equipment presents a reserve capacity. Further, it was observed that the feed and product size distributions for S-3 are quite close to each other. This indicates low reduction ratio of the pebble crusher, which could be due to the large operating gap (closed side setting).

Figure 6 and Table 9 present the particle size distributions and key performance indicators for the SAG mill, respectively. The SAG mill average feed size (Table 9) for survey $1(185 \mathrm{~mm})$ was significantly higher compared to surveys $2(102 \mathrm{~mm})$ and $3(122 \mathrm{~mm})$. The reason for this might be due to unmonitored gap of the primary crusher or feeder proportions from the stockpile. Since the design feed size for the SAG mill was $120 \mathrm{~mm}$, this higher feed size will have contributed to the poor grinding performance in survey 1 .

The hardness of the ore is an important parameter for SAG mill efficiency. Literature reports that, in SAG mills, soft ores are is mainly ground by impact breakage while hard ores are subjected to 
Assessment of the Performance of Grinding Circuit for Buzwagi Gold Mine

abrasion and attrition events where the

harder particles (Pourghahramani, 2012).

media impact could not sufficiently break

Table 7: BGM grinding circuit performance indicators as recorded/calculated during survey.

\begin{tabular}{|c|c|c|c|c|}
\hline \multirow[b]{2}{*}{ Stream/Unit name } & \multicolumn{3}{|c|}{ Survey } & \multirow[b]{2}{*}{ Target/Design } \\
\hline & S-1 & $\mathrm{S}-2$ & S-3 & \\
\hline \multicolumn{5}{|l|}{ SAG Mill } \\
\hline Throughput (t/h) & 618.72 & 674.11 & 573.35 & $543-566$ \\
\hline Power draw (kW) & 5387 & 6147 & 6198 & 6000 \\
\hline Dilution ratio & 0.54 & 0.45 & 0.37 & \\
\hline \multicolumn{5}{|l|}{ Ball Mill } \\
\hline Discharge $(\mathrm{t} / \mathrm{h})$ & 1109.91 & 939.83 & 487.42 & \\
\hline Power draw (kW) & 5294 & 5399 & 5230 & 6,000 \\
\hline$\%<125 \mu \mathrm{m}$ & 7.40 & 9.23 & 4.65 & 80 \\
\hline \multicolumn{5}{|l|}{ Hydrocyclone } \\
\hline Feed $(\mathrm{t} / \mathrm{h})$ & 1729.04 & 1613.93 & 1060.74 & 1462 \\
\hline Underflow (t/h) & 1387.48 & 1249.57 & 840.08 & \\
\hline Overflow (t/h) & 341.82 & 363.90 & 220.66 & \\
\hline Circulating load, $C \mathrm{~L}(\%)$ & 400.00 & 344.00 & 381.00 & $250-350$ \\
\hline
\end{tabular}

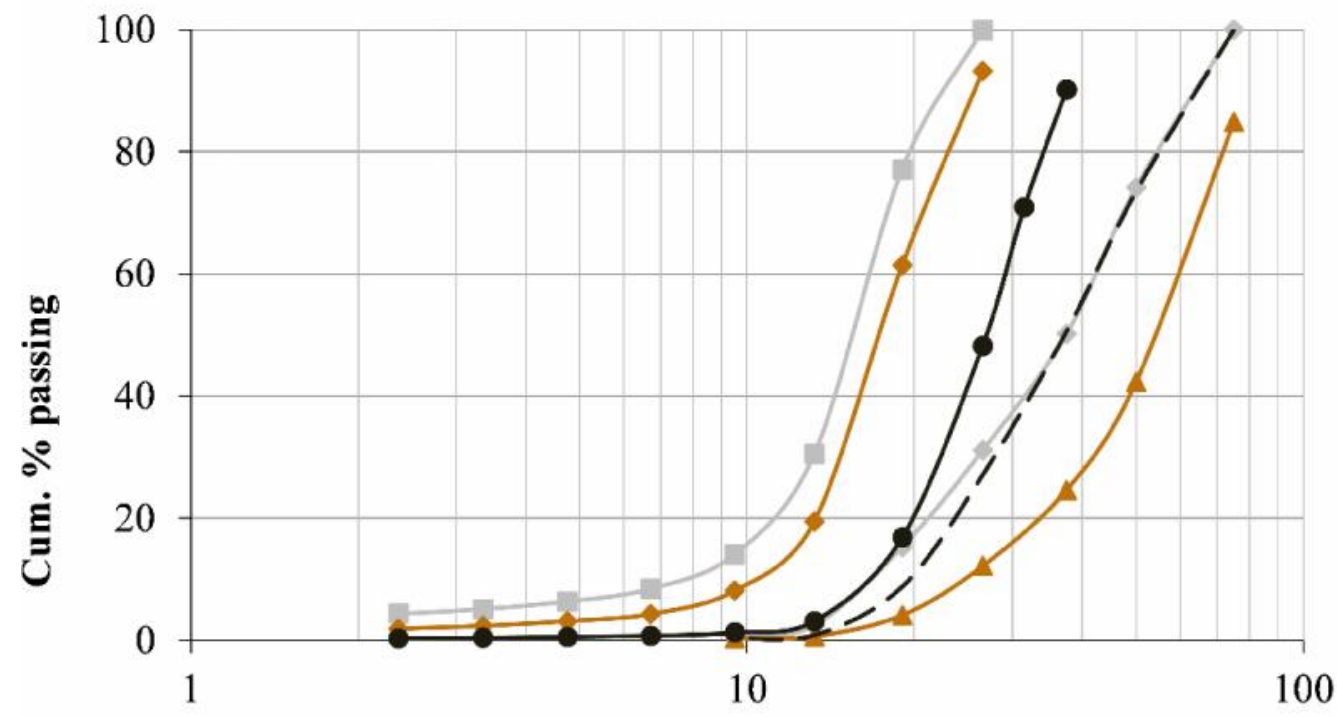

Particle size $x$ in $\mathbf{m m}$

\begin{tabular}{|c|c|c|}
\hline$\leadsto-$ Feed (survey 1) & $\longrightarrow-$ Feed (survey 2 ) & -- Feed (survey 3 ) \\
\hline - Product (1) & $\leadsto$ Product $(2)$ & $\rightarrow-$ Product (3) \\
\hline
\end{tabular}

Figure 5: Pebble crusher streams particle size distribution 
Table 8: Pebble crusher performance indicators.

\begin{tabular}{|c|c|c|c|c|}
\hline Parameter & S-1 & S-2 & S-3 & Design \\
\hline CSS $(\mathrm{mm})$ & 12 & 13 & 20 & $14 / 10$ \\
\hline Feed $(\mathrm{t} / \mathrm{h})$ & 61.01 & 70.45 & 68.53 & 190 \\
\hline$x_{\mathrm{F}, 80}(\mathrm{~mm})$ & 56 & 72 & 56 & \\
\hline$x_{\mathrm{P}, 80}(\mathrm{~mm})$ & 20 & 23 & 34 & \\
\hline
\end{tabular}

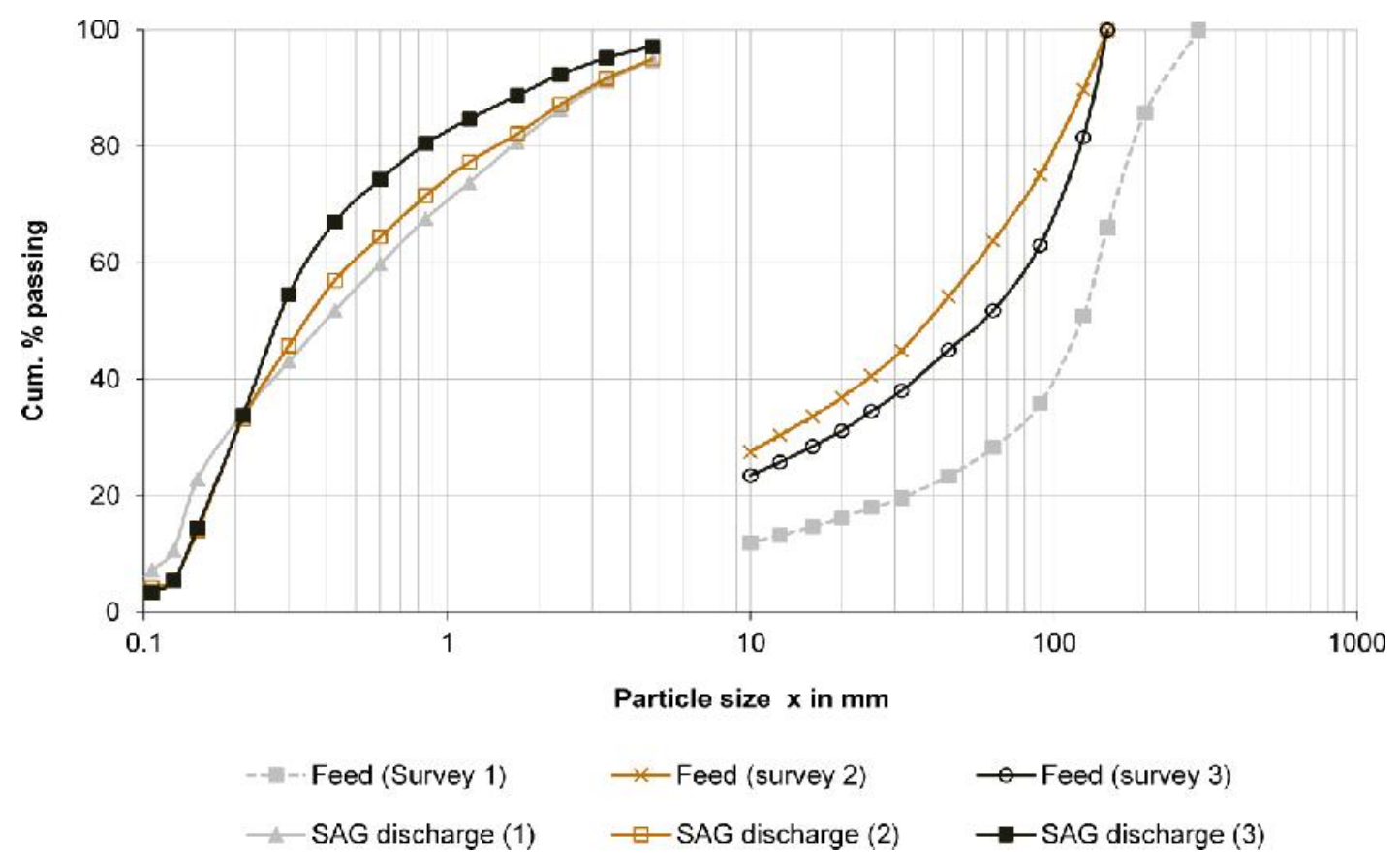

Figure 6: SAG mill feed and product particle size distribution for survey 1, 2 and 3

This can be reflected in this study, whereby, the harder the feed (Table 6), the finer the SAG mill product (Table 9). This had also an influence on the overall circuit product size (i.e. ball mill product). It can further be observed that, SAG mill products size was influenced by the specific energy. The higher the energy input employed, the finer becomes the final product size and vice versa as could be expected. Moreover, the reduction ratios achieved by the SAG mill were within recommendation.

The observed fluctuation in SAG mill feed size is a problem that needs to be addressed. Regular monitoring and control of the SAG feed size is important as the change in feed size distribution normally results to corresponding changes in the grinding media size distribution, which has further impact on power and throughput (Napier-Munn et al., 1996; Wills et al., 2006). This could be achieved through regular monitoring of the primary crusher performance through analysis of the product size distribution. Since the SAG mill is fed by the ore drawn from the stockpile through three feeders, the SAG mill feed size distribution could also be influenced by the proportion or ratios at which the feeders draw the ore. Hence, closer control of the feeders is also important. 
Table 9: SAG mill performance indicators.

\begin{tabular}{|l|c|c|c|c|}
\hline Parameter & S-1 & S-2 & S-3 & Design \\
\hline SAG mill feed rate $(\mathrm{t} / \mathrm{h})$ & 618.72 & 674.11 & 573.35 & $543-566$ \\
\hline SAG mill feed, $x_{\mathrm{F}, 80}(\mathrm{~mm})$ & 185.45 & 101.6 & 122 & 120 \\
\hline SAG discharge $x_{\mathrm{P}, 80}(\mathrm{~mm})$ & 1.644 & 1.468 & 0.831 & \\
\hline SAG mill reduction ratio $(-)$ & 113 & 69 & 147 & \\
\hline SAG mill specific energy $(\mathrm{kWh} / \mathrm{t})$ & 7.92 & 8.26 & 9.47 & \\
\hline Ball load, $\%$ volume & 14.30 & 14.30 & - & $15-20$ \\
\hline Material load, \% volume & 20 & 20 & - & $30-35$ \\
\hline
\end{tabular}

\section{Ball Mill Circuit}

The particle size distribution of ball mill streams is presented in Figure 7. Little can be seen in terms of differences in the ball mill performance for the three surveys. Based on the product fineness and reduction ratios (Table 12), it can be seen that the ball mill operation was inefficient. The poor performance might have been due to higher circulating load (Table 7) and coarser SAG mill discharge (Table 9)experienced by the operation. Further, the efficiency of the ball mill is seen to depend on the input energy as well as the circuit throughput (Table 7).

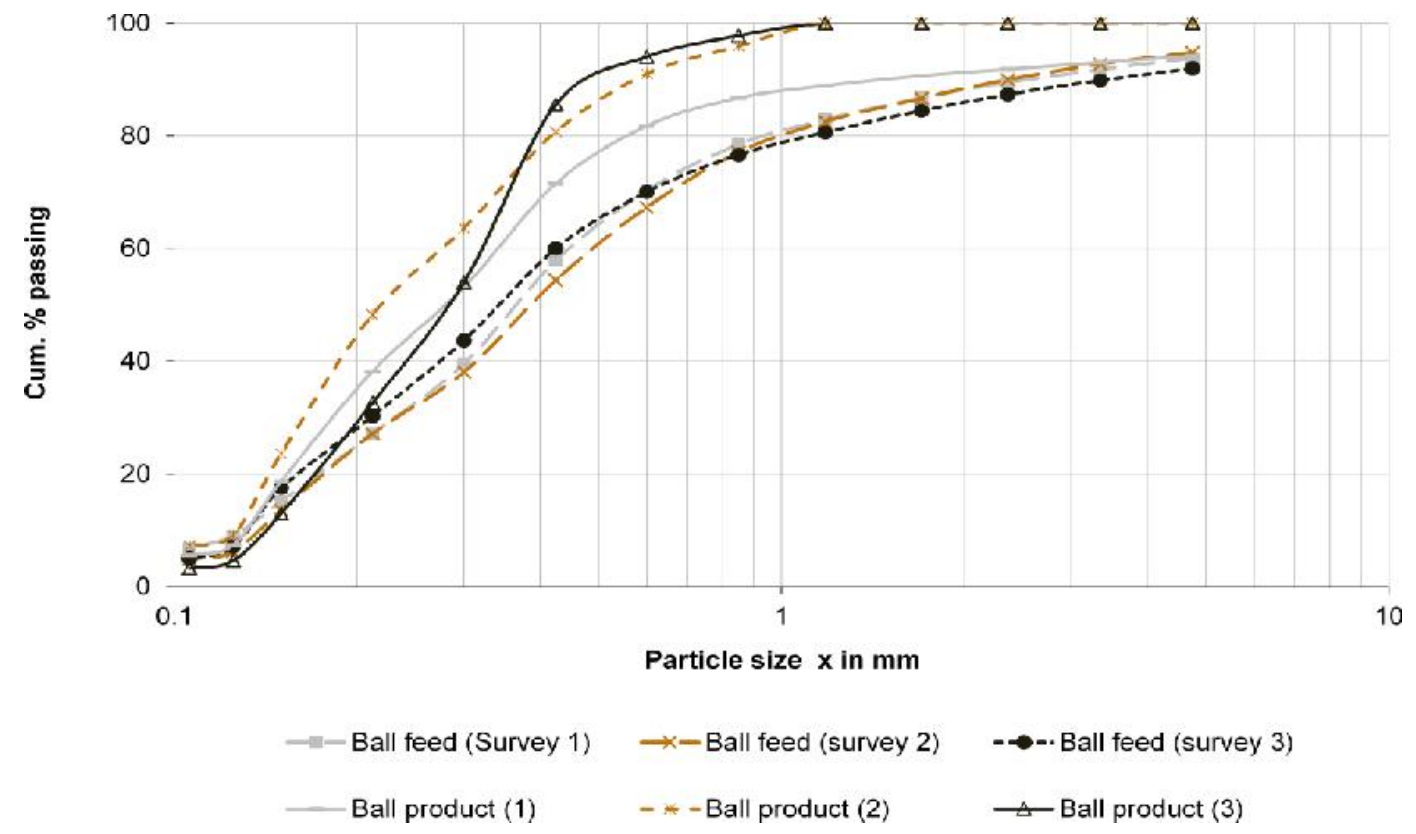

Figure 7: Ball mill feed and product particle size distribution for survey 1, 2 and 3

Figure 8 to Figure 11 and Table 11 to Table 13 present the results for the size distributions and some key performance indicators, respectively, for the BGM hydrocyclones obtained during the three surveys. The result shows that the overflow product size $\left(\mathrm{x}_{\mathrm{P}, 80}\right)$ is much coarser than target (i.e. $125 \mu \mathrm{m}$ ) in all surveys (Table 11). Since the ball mill products were significantly coarser than once designed, the coarse overflow achieved could also be contributed by the inefficient ball mill. Also the overflow size $\left(\mathrm{x}_{\mathrm{P}, 80}\right)$ is influenced by hydrocyclone feed rate and feed pulp density.

The growth of the feed rate increases the centrifugal force effect which causes finer 
particles being carried to the underflow, and hence decreasing the cut size. Further, the sharpness of separation decreases with increasing pulp density and the separation size rises due to higher resistance to swirling motion within the cyclone which

Table 10: Ball mill performance indicators.

\begin{tabular}{|l|c|c|c|c|}
\hline Parameter & S-1 & S-2 & S-3 & Design \\
\hline Ball mill feed $x_{\mathrm{F}, 80}(\mathrm{~mm})$ & 0.963 & 1.028 & 1.127 & \\
\hline Ball mill discharge $x_{\mathrm{P}, 80}(\mathrm{~mm})$ & 0.570 & 0.419 & 0.403 & 0.125 \\
\hline Ball mill reduction ratio $(-)$ & 1.70 & 2.45 & 2.80 & \\
\hline Ball mill specific energy $(\mathrm{kWh} / \mathrm{t})$ & 4.77 & 5.74 & 10.73 & \\
\hline Ball load, \% volume & 33 & 33 & - & $30-35$ \\
\hline
\end{tabular}

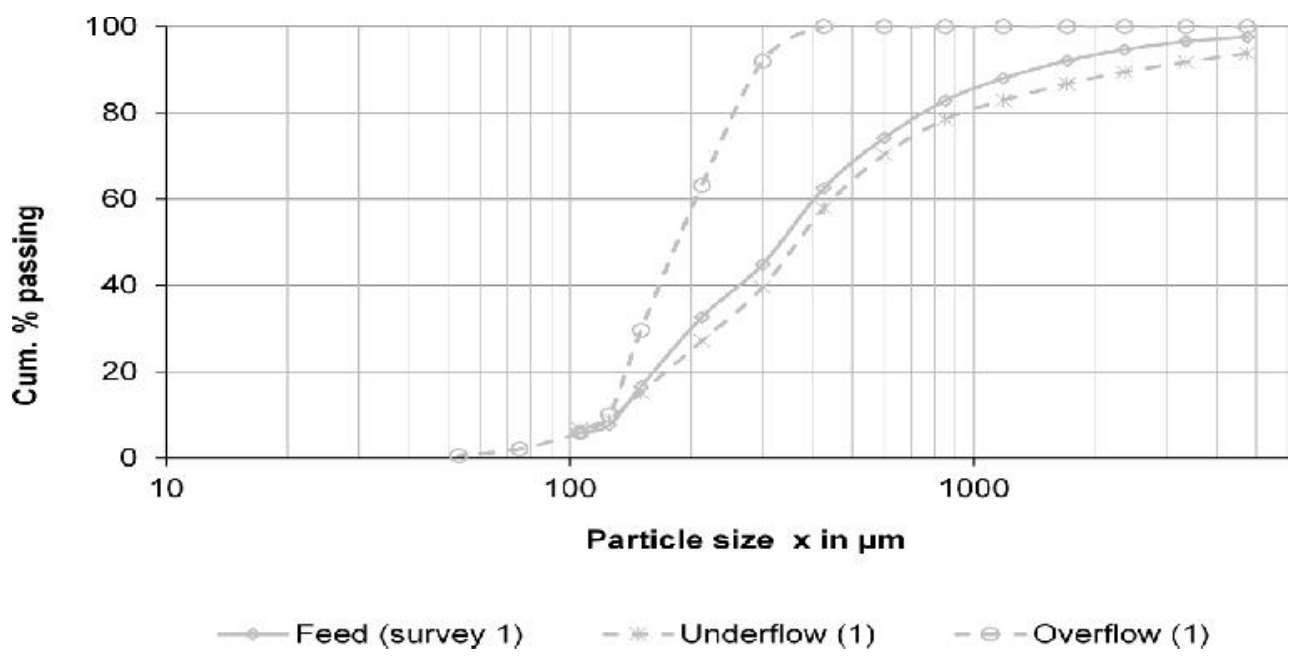

Figure 8: Hydrocyclone product streams particle size distribution for survey 1

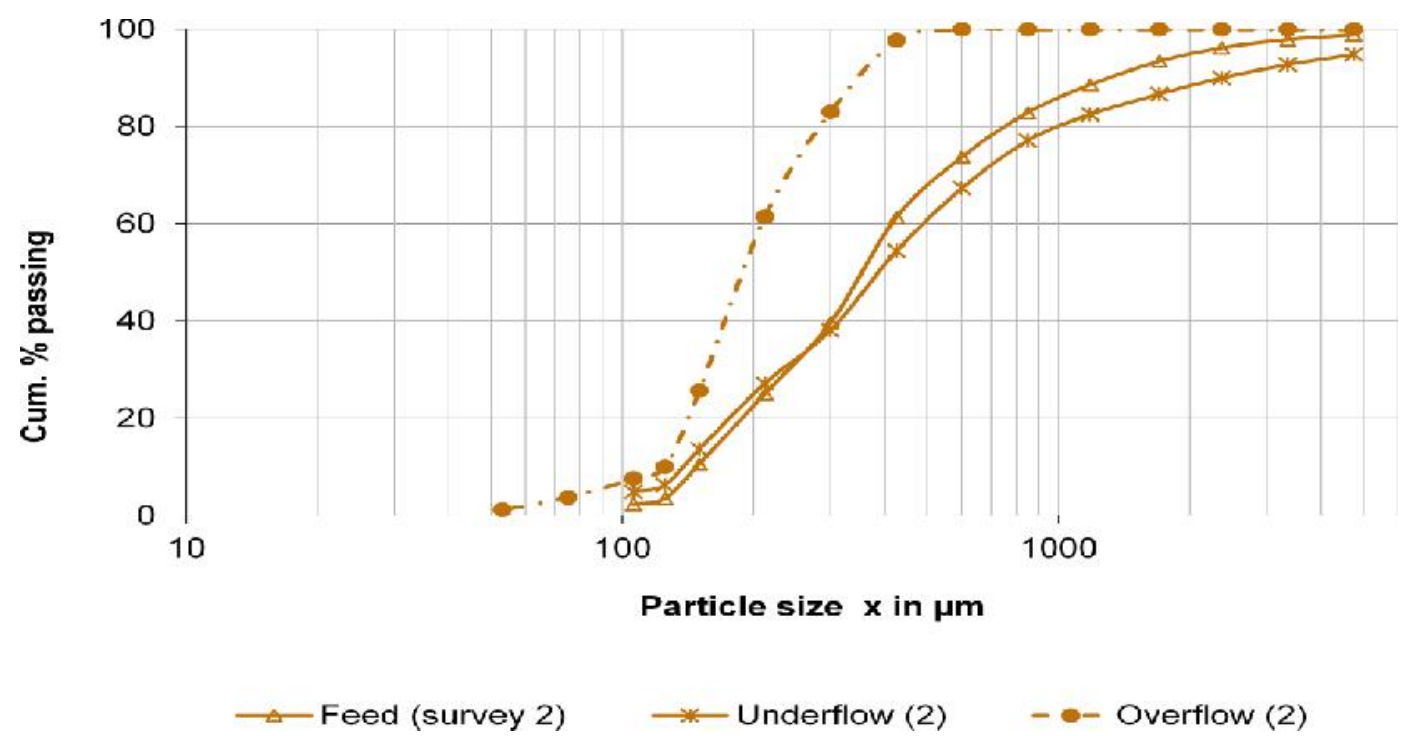

Figure 9: Hydrocyclone product streams particle size distribution for survey 2 
Table 11: Hydrocyclone performance indicators.

\begin{tabular}{|l|c|c|c|c|}
\hline Parameter & S-1 & S-2 & S-3 & Design \\
\hline Feed rate $(\mathrm{t} / \mathrm{h})$ & 1729 & 1614 & 1061 & 1462 \\
\hline Operating pressure $(\mathrm{kPa})$ & 98 & 81 & 92 & $80-110$ \\
\hline Feed volume-\% solids & 42 & 44 & 41 & 33 \\
\hline Underflow volume-\% solids & 57 & 57 & 56 & $48-56$ \\
\hline Overflow volume-\% solids & 20 & 24 & 21 & $13-16$ \\
\hline Feed $x_{\mathrm{P}, 80}(\mu \mathrm{m})$ & 768 & 771 & 570 & \\
\hline Underflow $x_{\mathrm{P}, 80}(\mu \mathrm{m})$ & 963 & 1028 & 1127 & \\
\hline Overflow $x_{\mathrm{P}, 80}(\mu \mathrm{m})$ & 266 & 288 & 241 & 125 \\
\hline
\end{tabular}

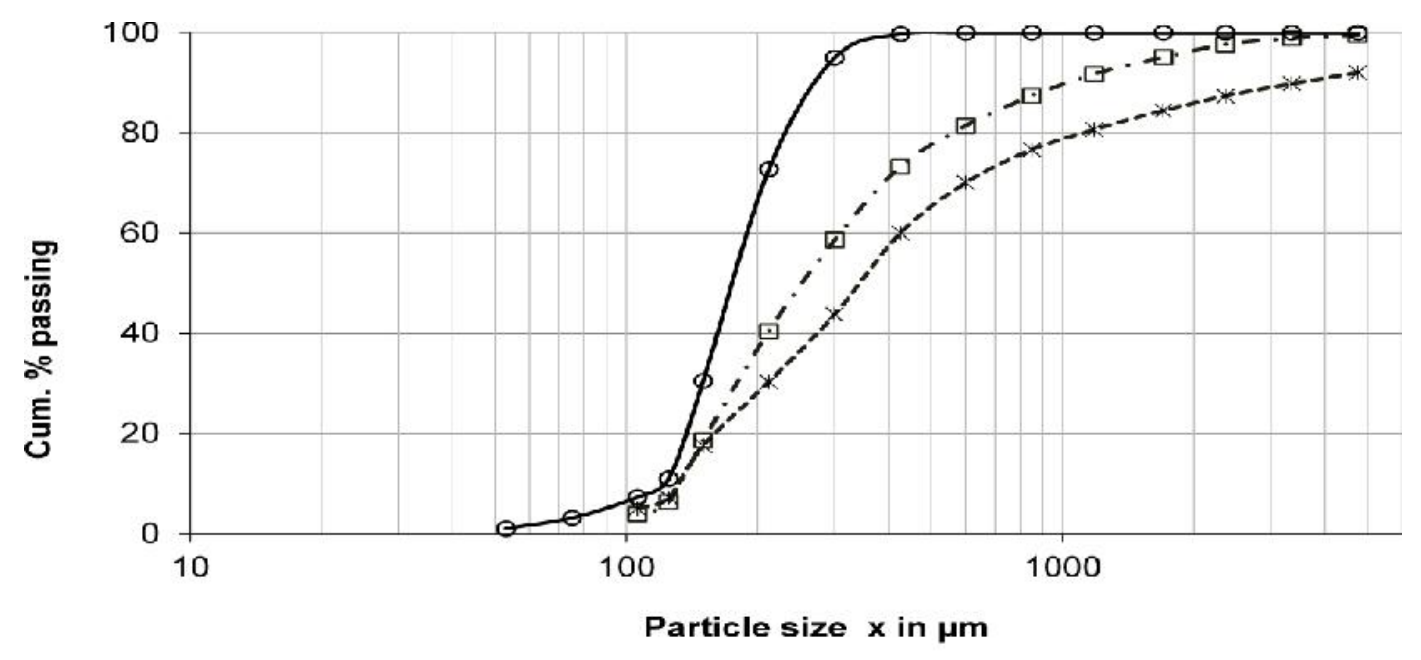

- - Feed (survey 3) --*-- Underflow (3) - - Overflow (3)

Figure 10: Hydrocyclone product streams particle size distribution for survey 3

The results of hydrocyclone efficiency for the BGM operation based on partition curves are shown in Figure 11. It can be observed that the by-pass fraction (split) was higher than $50 \%$ and the cut size was higher than $200 \mu \mathrm{m}$ for all three cases. This may also be related to the higher overflow $x_{\mathrm{P}, 80}$ obtained; clearly indicating that the current BGM operation is not able to achieve the target overflow size of 125 $\mu \mathrm{m}$. The cut size and the by-pass fraction are influenced by feed pulp density and feed rate (Table 9). This is conforming with previous studies (Rybinski et al., 2011; Wills et al., 2006). In all of the three surveys, the hydrocyclone feed volume- $\%$ solids was $17 \%$ higher than design (33 $\% \mathrm{v} / \mathrm{v})$ and also higher than recommended values from literature $(60 \%$ solids or $35 \%$ $\mathrm{v} / \mathrm{v})$. This is suspected to have contributed to the poor separation efficiency observed.

Nevertheless, the separation efficiency, $\kappa$ (Table 12) was fairly good for all surveys if the splitting effect was taken into account. The imperfection, $I$, can be used to categorize hydrocyclones (Guru and Basavaraj, 2012). Consequently, the hydrocyclones at BGM could be categorized (Table 13) between very good (i.e. $0.2<I<0.3$ ) and excellent (i.e. $I<$ 0.2 ). This indicates that the current design is in principle fairly efficient for coarser overflow product and not for the current BGM target (i.e. $x_{\mathrm{P}, 80}=125 \mu \mathrm{m}$ ).

Therefore, the inefficiencies shown by the higher values of cut size could probably be an indication of the unsuitability of the 
current design parameters for the target overflow of $125 \mu \mathrm{m}$. The influence of these design parameters on hydrocyclone cut size is clearly explained in literature (Schubert, 1985; Wills et al., 2006).

In practice, the selection of cut size is based on the designed size analysis of the overflow (Metso, 2010). For example, for BGM, the target overflow size amounts to $x_{\mathrm{P}, 80}=125 \mu \mathrm{m}$, then the recommended cut size for efficient operation is $132.50 \mu \mathrm{m}$ (obtained by multiplying target overflow size by the corresponding factor) in Table 14.

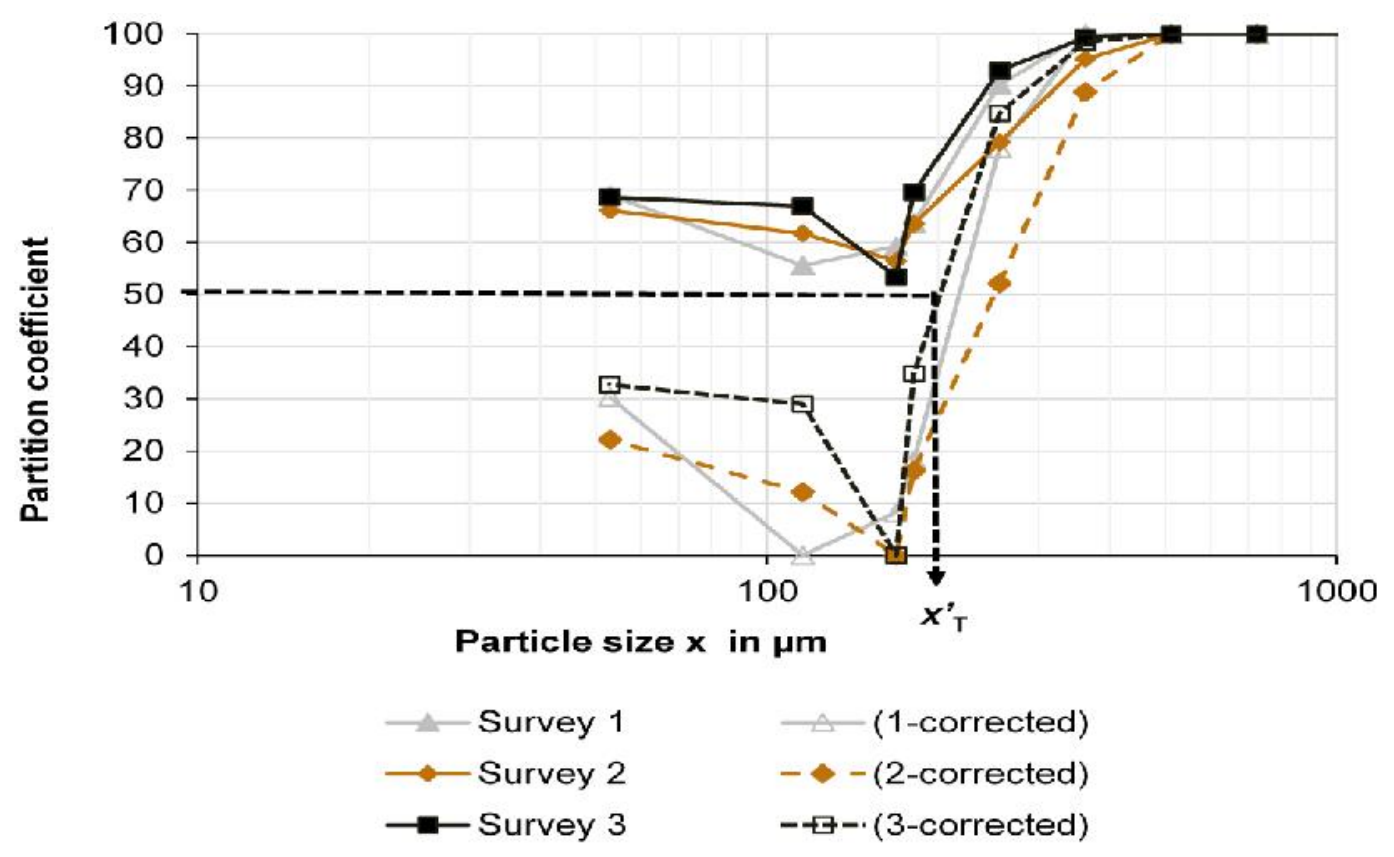

Figure 11: Hydrocyclone uncorrected and corrected efficiency curves for survey 1, 2 and 3

Table 12: Hydrocyclone efficiency indicators.

\begin{tabular}{|l|c|c|c|c|}
\hline Parameter & S-1 & S-2 & S-3 & Design \\
\hline By-pass fraction $(\%)$ & 55.60 & 56.00 & 53.42 & \\
\hline Cut size, $x_{\mathrm{T}}(\mu \mathrm{m})$ & 220.84 & 251.45 & 203.75 & \\
\hline Imperfection, $I$ & 0.14 & 0.24 & 0.16 & \\
\hline Sharpness Index, $\kappa$ & 0.75 & 0.62 & 0.74 & \\
\hline Overflow $x_{\mathrm{P}, 80}(\mu \mathrm{m})$ & 266 & 288 & 241 & 125 \\
\hline
\end{tabular}

Table 13: Hydrocyclone efficiency category based on imperfection, I.

\begin{tabular}{|l|l|}
\hline Imperfection, $I$ - values & Separator category \\
\hline$<0.2$ & Excellent separator \\
\hline $0.2<I<0.3$ & Very good separator \\
\hline $0.3<I<0.4$ & Medium separator \\
\hline $0.4<I<0.6$ & Poor separator \\
\hline$I>0.6$ & Bad separator \\
\hline
\end{tabular}


Table 14: Factors for conversion of $\%$ passing in the overflow to $X_{T}$.

\begin{tabular}{|l|c|c|c|c|c|c|c|}
\hline$\%$ passing in the overflow & 99 & 95 & 90 & 80 & 70 & 60 & 50 \\
\hline Factor & 0.49 & 0.65 & 0.79 & 1.06 & 1.36 & 1.77 & 2.34 \\
\hline
\end{tabular}

\section{Grinding Circuit Efficiency}

Table 15 summarize the energy efficiency characteristic for the BGM operation. As seen in Table 15, the operating work index is more than twice the laboratory work index for each of the three surveys. This implies that, the circuit consumes more energy than the laboratory Bond test estimate and hence does not conform to the Bond standards in terms of energy efficiency (Alamouti et al., 2011; Rowland, 2008). This can further be revealed by very low Bond efficiency factors (i.e. measure of the relative efficiency of the circuit compared to the prescribed Bond standard energy)of less than $65 \%$. Therefore, the operation is inefficient and could be optimized through decreased throughput.

The energy efficiency data (Table 16) reveal two options for the current BGM operation to achieve the target product size of $125 \mu \mathrm{m}$. A significant decrease in throughput by up to $44 \%$ or an increase in input energy by up to $80 \%$ (e.g. survey 1 ) are required in order to achieve such an improvement. The increase in input energy might be caused by the change in ore hardness. An increase in input energy requirement is not possible with the existing equipment, as this is equivalent to approximately $19 \mathrm{MW}$ as opposed to the existing equipment capacity of $12 \mathrm{MW}$.

Table 15: Energy consumption and operating work index for the current BGM operation.

\begin{tabular}{|l|l|l|l|l|}
\hline \multirow{2}{*}{ Parameter } & \multicolumn{3}{|c|}{ Survey } & Design \\
\cline { 2 - 5 } & $\mathrm{S}-1$ & $\mathrm{~S}-2$ & $\mathrm{~S}-3$ & \\
\hline Throughput $(\mathrm{t} / \mathrm{h})$ & 618.72 & 674.11 & 573.35 & $543-566$ \\
\hline Circuit power $(\mathrm{kW})$ & 10,681 & 11,546 & 11,428 & 12,000 \\
\hline Input Energy $(\mathrm{kWh} / \mathrm{t})$ & 17.26 & 17.13 & 19.93 & \\
\hline Operating $W_{\mathrm{i},},(\mathrm{kWh} / \mathrm{t})$ & 35.62 & 30.78 & 34.91 & \\
\hline$W_{\mathrm{i}}(\mathrm{kWh} / \mathrm{t})$ & 17.2 & 18.70 & 18.50 & $14.5-16.5$ \\
\hline Bond efficiency, $E(\%)$ & 48.30 & 60.70 & 52.90 & \\
\hline
\end{tabular}

Table 16: Input energy and throughput required for the current operation to achieve $\mathrm{X}_{\mathrm{P}, 80}$ of $125 \mu \mathrm{m}$

\begin{tabular}{|c|c|c|c|c|}
\hline Survey & $x_{\mathrm{F}, 80}$ in $\mathrm{mm}$ & $x_{\mathrm{P}, 80}$ in $\mu \mathrm{m}$ & $\begin{array}{c}\text { Throughput in } \mathrm{t} / \mathrm{h} \text { (compared to } \\
\text { actual throughput) }\end{array}$ & $\begin{array}{c}\text { Input energy in } \\
\mathrm{kWh} / \mathrm{t}\end{array}$ \\
\hline 1 & 185 & \multirow{2}{*}{125} & $344(-44.40 \%)$ & 31.03 \\
\hline 2 & 102 & & $435(-35.50 \%)$ & 26.56 \\
\hline 3 & 122 & & $378(-34.10 \%)$ & 30.22 \\
\cline { 1 - 1 } & & & \\
\cline { 4 - 5 } & &
\end{tabular}

\section{CONCLUSIONS}

Three full scale sampling campaigns and laboratory experimentation were conducted to evaluate the performance of
BGM grinding circuit. The work index of the Buzwagi gold ore during plant design ranged from 14.5 to $16.5 \mathrm{kWh} / \mathrm{t}$. The values obtained during the survey ranged between $17.20-18.70 \mathrm{kWh} / \mathrm{t}$. This 
indicates a change in the hardness of the ore during the last 7 years. Thus, a periodic review is required to assess the variation in hardness as mining progresses. This will help in establishing better blends and also predicting an appropriate tonnage for existing ore types, so as to be efficiently treated by existing capacity.

The comminution efficiency was determined using the Bond efficiency factor. Bond efficiency factors of 48-61\% were obtained for the BGM grinding operation, implying that the operation was inefficient and could probably achieve targets through reduced throughput. The SAG mill feed particle size distribution between the three surveys showed significant fluctuations $\left(x_{\mathrm{F}, 80}:\right.$ 102-185 $\mathrm{mm})$. Since SAG mills use ore as part of the grinding media, regular monitoring and control of the ore feed size distribution is recommended as the change in feed size distribution normally results to corresponding changes in the grinding media size distribution, which has further impact on power and throughput. This could be fixed through closer monitoring of the primary crusher performance and also control of the ratios of SAG mill feeders which draws the ore from the stockpile.

The assessment of survey data indicated that the inefficiency of the ball mill was contributed by inefficient hydrocyclones. Apart from running at approximately $17 \%$ above the design, hydrocyclones were also characterized by higher feed pulp densities (66.5-68.4\%). In overall, this led to an overload of the ball mill due to increased circulating load. Classification efficiency could be improved by dilution of the feed in order to lower the pulp density, which could also improve the overflow density (i.e. closer to $30 \%$ ) and hence giving a sharper cut.

Hence, an optimization study by computer simulation is further recommended. Through simulation of multi-effects, a deeper understanding of the efficiency problems for the BGM grinding operation will be facilitated and also may provide possible solutions. As the operations at BGM are close to an end, the findings from this study could be useful to other mining operations with similar problem.

\section{ACKNOWLEDGEMENTS}

The author would like to thank Buzwagi Gold Mine for allowing sampling at their plant as well as transportation of ore material to Germany for more test works. The Institute of Mechanical Process Engineering and Mineral Processing, TU Bergakademie Freiberg is also acknowledged for provision of laboratory facilities for the investigation.

\section{REFERENCES}

Acar C. (2013). Investigation of Particle Breakage Parameters in Locked-cycle Ball Milling. PhD Thesis, Middle East Technical University.

Alamouti B., Rezai B. and Noaparast M. (2011). Grinding Circuit at Mouteh Gold Mine. Amirkabir/MISC, 43(2): 71-76.

Ballantyne G., Powell M. and Tiang M. (2012). Proportion of Energy Attributable to Comminutione, in: 11th Mill Operators' Conference. Hobart.

Bond F.C. (1961). Crushing and grinding calculations, Part I-II. Br. Chem. Eng., 153: 362-373.

Bond F.C. (1952). The Third Theory of Comminution. Trans. AIME 193: 484494.

Bond F.C. and Maxson W.L. (1943). Standard grindability tests and calculations. Transactions 153: 362373.

Boucaut S. (2017). Energy in Mining. [WWW Document]. URL https://ceecthefuture.org/why-smartcompanies-are-focusing-oncomminution/. (accessed on 11.28.20). 
Curry J.A., Ismay M.J.L. and Jameson G.J. (2014). Mine operating costs and the potential impacts of energy and grinding. Miner. Eng. 56: 70-80. https://doi.org/10.1016/j.mineng.2013.1 0.020

Danha G. (2013). Identifying Opportunities for Increasing the Milling Efficiency of a Bushveld Igneous Complex (BIC) Upper Group (UG) 2 Ore. University of Witwatersrand, South Africa.

Deniz V. (2011). Computer Simulation of Product Size Distribution of a Laboratory Ball Mill. Part. Sci. Technol. 29: 541-553. https://doi.org/10.1080/02726351.2010. 536303

Fuerstenau D.W., Phatak P.B., Kapur P.C. and Abouzeid A.Z.M. (2011). Simulation of the grinding of coarse/fine (heterogeneous) systems in a ball mill. Int. J. Miner. Process., 99: $32-38$.

https://doi.org/10.1016/j.minpro.2011.0 2.003

Gupta A. and Yan D.S. (2006). Introduction to Mineral Processing Design and Operation. Perth, Australia.

Guru N.M. and Basavaraj K. (2012). Assessing the performance of a floatex density separator for the recovery of iron from low-grade australian iron ore fines - a case study, in: XXVI International Mineral Processing Congress (IMPC). New Delhi, India.

Jeswiet J. and Szekeres A. (2016). Energy Consumption in Mining Comminution. Procedia CIRP 48: 140-145. https://doi.org/10.1016/j.procir.2016.03. 250

Khumalo N. (2007). The Application of the Attainable region analysis in Comminution. University of the Witwatersrand, South Africa.

Leißner T., Hoang D.H., Rudolph M., Heinig T., Bachmann K., Gutzmer J., Schubert H. and Peuker U.A. (2016). A mineral liberation study of grain boundary fracture based on measurements of the surface exposure after milling. Int. J. Miner. Process. 156: 3-13. https://doi.org/10.1016/j.minpro.2016.0 8.014

Magdalinović N. (1989). A procedure for rapid determination of the Bond work index. Int. J. Miner. Process. 27: 125132. http://dx.doi.org/10.1016/03017516(89)90010-0

Man Y.T. (2002). Why is the Bond Ball Mill Grindability Testdone the way it is done? Eur. J. Miner. Process. Environ. Prot., 2: 34-39.

Masuda H., Higashitani K., Yoshinda H. (2007). Powder Technology: Handling and Operations, Process Instrumentation, and Working Hazards. Taylor and Francis, Boca Raton.

Metso (2010). Basics of mineral processing. Metso, Helsinki, Finland.

Mosher J.B. and Tague C.B. (2001). Conduct and precision of bond grindability testing. Miner. Eng., 14(10): 1187-1197. https://doi.org/10.1016/S08926875(01)00136-4

Mular A.L., Haibe D.N. and Barrett D.J. (2002). Mineral Processing Plant Design, Practice, and Control. SME.

Napier-Munn T.J., Morrel S. and Kojovic T. (1996). Mineral Comminution Circuits: Their Operation and Optimisation, JKMRC Monograph Series in Mining and Mineral Processing 2. JKMR, Queensland, Australia.

NRC (1981). Comminution and Energy Consumption. Washington DC.

Pourghahramani P. (2012). Effects of ore characteristics on product shape properties and breakage mechanisms in industrial SAG mills. Miner. Eng., 32: 30-37.

https://doi.org/10.1016/j.mineng.2012.0 3.005

Rosario P.P. (2010). Comminution Circuit Design and Simulation for the Development of a Novel High Pressure Grinding Roll Circuit. University of 
British Columbia.

Rowland C.A. (2008). The Standard for Comminution Efficiency, in: SME Annual Meeting. SME, Salt Lake City, Uhah, USA.

Rowland C.A. (2006). Bond's Method for Selection of Ball Mills, in: Advances in Comminution. SME, Littleton, Colorado, USA.

Rybinski E., Ghersi J., Davila F., Linares J., Valery W., Jankovic A., Valle R., and Dikmen S. (2011). Optimisation and continuous improvement of Antamina comminution circuit, in: SAG Conference. Vancouver, Canada.

Saramak D., Tumidajski T., Bro ek M., Gawenda T. and Naziemiec Z. (2010). Aspects of comminution flowsheets design in processing of mineral raw materials. Gospod. Surowcami Miner., 26: 59-69.

Schlanz J.W. (1987). Grinding: An Overview of Operation and Design . Mill Oper. Symp.

Schubert H. (2003). "Zu den Ursachen 'anomaler' Verläufe der Trennkurve bei der Feinstkornklassierung in Hydrozyklonen - insbesondere zum so genannten Fish-Hook-Effekt*)." Aufbereit. Tech., 44: 5-17.

Schubert H. (1985). A hydrocyclone separation model in consideration of the turbulent multi-phase flow. Part. Sci. Technol., 3 : 1-13. https://doi.org/10.1080/0272635850890
6423

Schubert H. and Mühle K. (1991). The role of turbulence in unit operations of particle technology. Adv. Powder Technol., 2: 295-306. https://doi.org/10.1016/S09218831(08)60696-2

Tromans D. (2008). Mineral comminution: Energy efficiency considerations. Miner. Eng., 21: 613-620. https://doi.org/10.1016/j.mineng.2007.1 2.003

Vedat D. (2011). Influence of interstitial filling on breakage kinetics of gypsum in ball mill. Adv. Powder Technol., 22: 512-517. http://dx.doi.org/10.1016/j.apt.2010.07. 004

Wikedzi A. (2018). Optimization and Performance of Grinding Circuits: The Case of Buzwagi Gold Mine (BGM). TU Bergakademie Freibergy.

Wills B.A. and Finch J.A. (2016). Wills' Mineral Processing Technology: An Introduction to the Practical Aspects of Ore Treatment and Mineral Recovery. Elsevier, Oxford.

Wills B.A., Napier-Munn T. and NapierMunn T. (2006). Wills' Mineral Processing Technology: An Introduction to the Practical Aspects of Ore Treatment and Mineral Recovery, 7th ed. Butterworth-Heinemann, Oxford. 